\title{
Petrogenesis and Tectono-Magmatic Setting of Meso-Cenozoic Magmatism in Azerbaijan Province, Northwestern Iran
}

\author{
Hemayat Jamali1,2, Abdolmajid Yaghubpur², Behzad Mehrabi², \\ Yildirim Dilek ${ }^{3}$, Farahnaz Daliran ${ }^{4}$ and Ahmad Meshkani ${ }^{2}$ \\ ${ }^{1}$ Geological Survey of Iran, Tehran \\ ${ }^{2}$ Tarbiat Moallem University, Tehran \\ ${ }^{3}$ Department of Geology, Miami University, Oxford, $\mathrm{OH}$ \\ ${ }^{4}$ Institute for Applied Geosciences, University of Karlsruhe, Karlsruhe \\ 1,2Iran \\ 3 USA \\ ${ }^{4}$ Germany
}

\section{Introduction}

There are widespread Cenozoic magmatic rocks in the prei-Arabian part of northern Zagros suture zone, which form the continental crust of this part of Alpine - Himalayan orogenic belt (Fig. 1). Although the age of these rocks ranges from Cretaceous to Quaternary, but the main magmatic phases belong to Cretaceous, upper Eocene- Oligocene, upper MiocenePliocene and plio-Quaternary. The magmatism occurred in Meso-Cenozoic periods due to convergence of the Arabian and Eurasian plates. The time and space distribution of MesoCenozoic magmatism in Azerbaijan between Arabian and Eurasian plates and their tectonic setting, are the major question in geodynamics of the eastern Mediterranean and Eastern Alpine-Himalayan belt.

In this paper, new geochemical data of Cenozoic magmatic rocks of Arasbaran region (analyzed by XRF method in Miami University) are used for interpreting petrogenesis of these rocks and determining their origin, nature of magma and its evolution. The time and space distribution of Late Mesozoic- Cenozoic magmatic rocks of the study area are also compared with the adjacent region in Azerbaijan, Armenia and Eastern Turkey. The authors try to find the relationship between magmatism and mineralization in time and space and to locate the probable occurrence of different types of mineralization associated with various magmatic events in the study area.

\section{Regional geology}

The broad Tethyan orogen had been evolved during a series of successive collisions between Eurasia and the rifted fragments of Gondwana land (Shengor and Natal'in, 1996). Rifting of ribbon-like continental fragments (i.e. Central Iran, South Armenia and Tauride blocks) from Gondwana occurred in the late Paleozoic-early Mesozoic, and discrete Tethyan ocean 


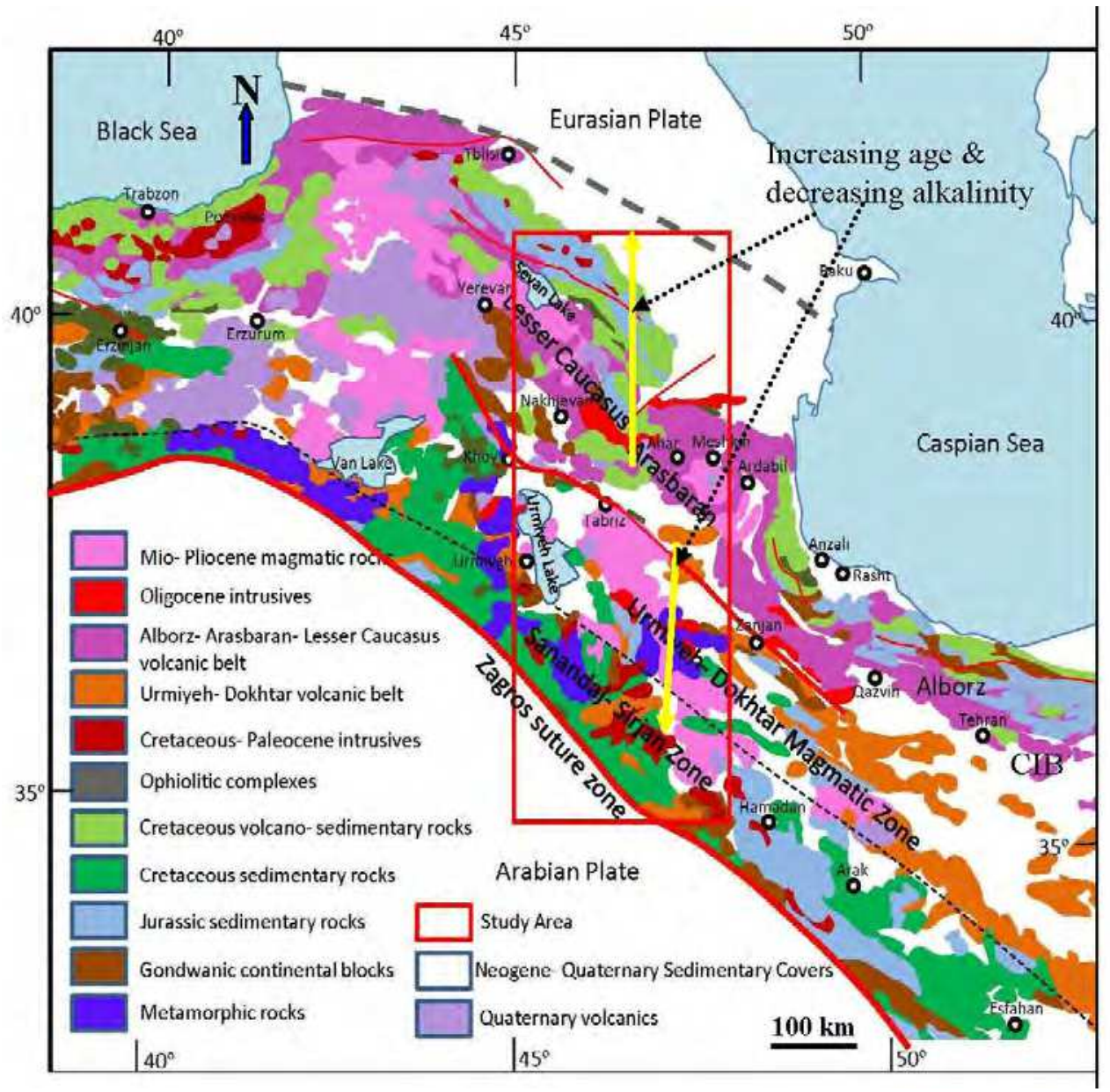

Fig. 1. Geological map of Tethyan belt from Central Iran to Eastern Turkey (modified from Aghanabati, 1993).

basins developed in the wake of these northward-migrating continental blocks (Dilek et al., 2010). The results of the collided segments of Gondwana land and Arabian plate with Eurasian plate were the construction of Zagros thrusted mountain range trending NW- SE in the western part of Iran, and Alborz-Azerbaijan mountain range in the northern to northwestern parts of the country. Four major tectono-magmatic zones; Sanandaj-Sirjan zone (SSZ), Urumieh- Dokhtar magmatic belt (UDMB), Central Iran Block (CIB) and AlborzArasbaran- Lesser Caucasus Belt (AALCB) in northwest of Iran are the result of geodynamic evolution of Tethys belt formed between Arabian and Eurasian plates during Early Mesozoic to Late Cenozoic (Fig. 1).

These Tectono-magmatic zones could be divided into smaller magmatic-metallogenic subzones such as Songhor-Baneh subzone, Sanandaj Cretaceous volcanic subzone and Tabriz-Hamadan subzone situated in the tectono-magmatic zone between Tabriz fault and 
Zagros thrust fault (Azizi, 2009). Blourian (1994) divided the magmatism of northern Iran into two subzones: Alborz subzone and West Alborz- Azerbaijan subzone. Jamali et al. (2010) recognized three magmatic-metallogenic subzones in the Ahar-Arasbaran-Lesser Caucasus area.

\subsection{Sanandaj-Sirjan Zone (SSZ)}

Sanandaj-Sirjan metamorphic-magmatic zone trending NW-SE is extending from south of Iran to southeast of Turkey parallel to the main Zagros thrust fault. Many geologists believe that the subduction of Arabian plate under the SSZ had been occurred in the place of main Zagros thrust fault where the ophiolites are situated along the thrust (Takin, 1972; Dewey et al., 1973; Berberian and Kings, 1981; Shengor, 1990; Hesami et al., 2001; Talebian and Jakson, 2004). On the other hand, Alavi (2007) believes that the suture zone between the Arabian plate and Iran lies between the SSZ and UDMB.

The northern part of the SSZ includes upper Paleozoic and Mesozoic metamorphic rocks with Meso-Cenozoic intrusive bodies. The age of these intrusions (Fig. 2) ranges from 170 to $40 \mathrm{Ma}$ (Ghalamghash, 2009; Mehrabi et al., 2009; Ghaderi et al., 2009). These bodies are composed of granite, granodiorite, syenite and diorite that belong to medium potassium calc-alkaline series, and from genetic point of view, they belong to I, A and S type granitoids, and are formed during syn- to post-collision environments in subduction zones (Ghalamghash, 2009; Mazhari et al., 2009). In addition to intrusive events, two volcanic subzones were also recognized in SSZ (Azizi, 2009). Songhor-Baneh subzone (5 to $10 \mathrm{~km}$ wide and extending about $200 \mathrm{~km}$ ) is composed of volcanic-sub-volcanic facies including basalt, gabbro and diorite with tholeiitic to calk-alkaline characteristics. In some places, the rocks are metamorphosed to greenschist and amphibolite facies. The age of these volcanic rocks using K-Ar dating method (Moinvaziri et al., 2008) is Late Eocene-Miocene (42-27 Ma). Azizi et al. (2009) believed that the BanehSonghor subzone that formed between the ophiolite suture zone (Campanian-Maastrichtian) and the SSZ belongs to an oceanic arc and it is the result of subducted Neo-Tethys oceanic crust under another fragment of the oceanic crust.

Another volcanic subzone belongs to the Late Cretaceous including mafic to intermediate rocks of calc-alkaline affinity. This subzone with $15-20 \mathrm{~km}$ width and $300 \mathrm{~km}$ length extends from Saghez to Piranshahr.

Differentiated REE pattern (Fig. 5), low $\mathrm{Ti}$, high $\mathrm{Al}$ and negative $\mathrm{Nb}$ anomaly are indicative of continental margin subduction zone (Azizi, 2009). Barika barite- and gold-rich massive sulfide deposit is associated with this volcanism (Tajeddin, oral communication).

According to Ghalmghash (2009), the subduction of Arabian plate under the SSZ had been started in the Early Cretaceous, and the first magmatic activities are related to the subduction zone. He believes that the magmatism that occurred after Campanian ( $80 \mathrm{Ma})$ is not related to subduction and it is originated from the crust, formed due to the collision between Arabian margin and the SSZ. Mazhari (2009) believes that the Piranshahr intrusive bodies of $41 \mathrm{Ma}$ belong to post collision event and the age of the collision between Arabian plate and the SSZ occurred in Late Cretaceous, while Omrani et al. (2008) and Azizi (2009) think that the collision was much younger and it occurred in the Late Miocene.

Gold mineralization (55.7-38.5 Ma) in metamorphic rocks (schist and amphibolite) of the SSZ (e.g. Muteh deposit and Saghez region) shows intrusion-related characteristics rather than orogenic mineralization. Magmatic phases, which are simultaneous with mineralization, are reported in the SSZ (Moritz et al., 2006; Tajeddin, oral communication). 
There is no mark about the porphyry and epithermal mineralization associated with Mesozoic-Paleogene magmatism in the SSZ.

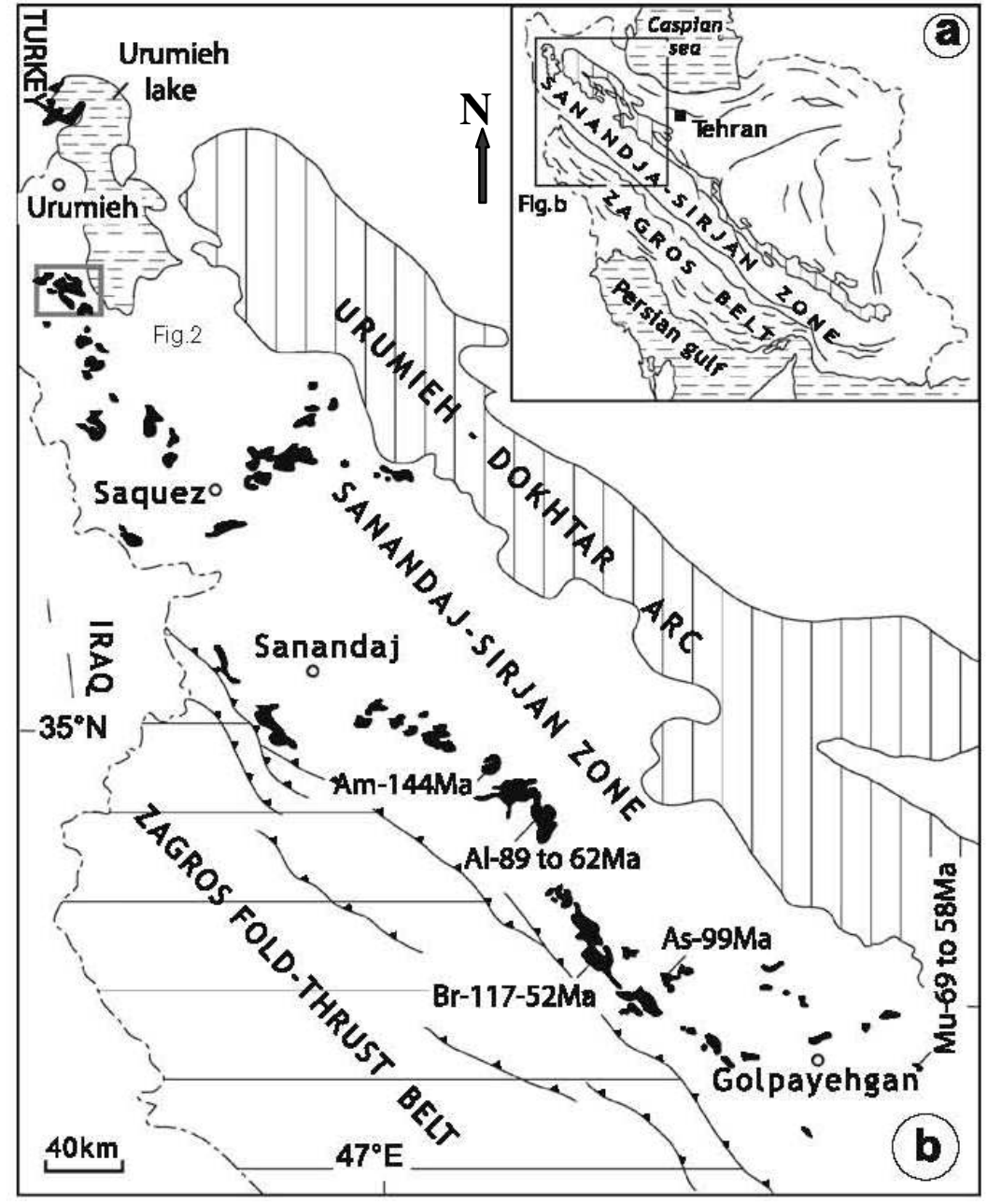

Fig. 2. (a) Tectonic setting of the Zagros orogenic belt in western Iran (b) Distribution of the Urumieh-Gholpaiegan plutonic belt (in black) in the SSZ. The ages of plutonic bodies are given in Ma, (Ghalamghash, 2009).

\subsection{Urumieh-Dokhtar magmatic belt(UDMB)}

Urumieh-Dokhtar magmatic belt trending NW-SE parallel to the SSZ (50 to $80 \mathrm{~km}$ wide) extends from south to northwest of Iran, situated next to Tabriz fault in northeast of this zone. There are some volcanic rocks cropping out in the south of Sarab. Magmatic activities in this belt started in the Eocene and continued until Quaternary (Omrani, 2008; Azizi, 2009). Magmatic activities are divided into two phases: a) volcanic activities in Eocene followed by 
intrusive activities in Oligocene, and b) magmatic activities started in the Late Miocene and continued to Quaternary. Data of major and trace elements in UDMB indicate the characteristics features of calc-alkaline magmatism related to continental margin subduction zones. REE pattern of these rocks is also indicative of mantle origin for the Eocene volcanic rocks (Omrani, 2008). On the contrary, the patterns of major and minor elements of the Late Miocene volcanic rocks, with adakite characteristics, are indicative of the break off of subducted slab and post collision process (Omrani, 2008). Omrani (2008) also believes that the Late Miocene collision and breakage of subducted slab in UDMB is simultaneous with the same event in the southeast of Turkey that occurred in 5-10Ma ago (Keskin, 2003).

Eocene volcanic rocks are associated with manto-type copper mineralization (e.g. Sarab and Mianeh regions). Recent studies indicate the probable existence of porphyry type mineralization in the Hashtrud- Mianeh region accompanying Oligocene plutonism that intruded the Eocene volcanic rocks (Jamali, 2011; unpublished data). Miocene magmatism with an adakitic signature and mildly alkaline affinity is accompanied with epithermal and Carlin type gold mineralization in Ghorveh and Takab regions (Mehrabi et al., 1999; Richards, 2006 and 2009).

\subsection{Central Iran Block (CIB)}

There are scattered exposures of the CIB, overlain by the Cenozoic volcanic rocks in northeast of UDMB and Alborz-Azerbaijan mountain ranges. These rocks, cropping out in the study area, are pre-Triassic sedimentary rocks that are similar to those of the south Armenia and Tauride blocks in Turkey. According to Sosson et al. (2005) and Dilek et al. (2010), Central Iran, Armenia and Tauride blocks were formed the northern margin of the Gondwana land prior to Triassic rifting. These three blocks include Precambrian crystalline basement overlain by Paleozoic-Mesozoic sedimentary sequences (Dilek, 2009; Roland, 2009; Sosson, 2005), separated from Gondwana land in the Late Triassic and joined the southern margin of the Eurasian plate during Late Cretaceous-early Paleocene (Dilek, 2009; Roland, 2009). Paleomagnetic investigations on Middle Triassic igneous rocks in Sumkhit- Gharebagh (Azerbaijan) and south Armenia indicate that the latitude was at about $22^{\circ} \mathrm{N}$ for the time of their formation (Sosson, 2005). The Paleo-Tethys Ocean started closing as the Neo-Tethys Ocean opened during separation of Central Iran, Armenia and Tauride blocks from the Gondwana land moving northwards. According to Bazhenov et al. (1996), the site of paleo-Tethys ocean enclosure is the present place of Sumkhit-Gharabagh-Black Sea area.

\subsection{Alborz-Arasbaran-Lesser Caucasus Belt (AALCB)}

The Transcaucasian Massif includes Pan-African orogenic crust intruded by latest Proterozoic to Palaeozoic granitoids, experienced multiple deformation and migmatitization, and the Jurassic to Early Cretaceous plutons representing a magmatic arc (Zakaridze et al., 2007). This arc continued into the Eastern Pontide blocks in the west.

A Cretaceous island arc complex with calc-alkaline to alkaline extrusive rocks, and pyroclastic deposits, flysch units and marl-limestone rocks occurs north of the Sevan-Akera suture zone (Dilek et al., 2010).

Cenozoic magmatic rocks of the AALCB are mainly acidic to basic volcanic rocks and acidic to intermediate intrusive bodies, with calc-alkaline to alkaline affinities trending NW-SE and located in the northwestern Iran and Caucasus mountain ranges (Moayed, 2001; Jamali et 
al., 2010). Similar to UDMB, magmatic activities in this belt have been started in the Eocene and continued to Quaternary.

Azizi et al. (2009) and Alavi (2007) believe that the scattered pieces of ophiolites around Tabriz fault are the remnants of UDMB back-arc oceanic crust (basin) and its subduction was the cause of the formation of Alborz-Arasbaran magmatic belt. There are scattered exposures of ophiolites and metamorphic rocks from Anzali to Sevan- Akera at northern margin of the AALCB (Fig. 1) (Galoyan et al., 2009; Berberian et al., 1981; Jamali et al., 2010). Based on isotopic data, the formation of Sevan-Akera ophiolites have started in the MiddleLate Jurassic and continued to Early Cretaceous (Galoyan et al., 2009). According to Sosson (2005), based on interlayering of radiolarites and pillow basalts, the age of ophiolites in the northern Armenia is proposed to be Late Jurassic. The exposure sites of these ophiolites could be the site of the Mesozoic ocean that was closed in Late Cretaceous-Early Paleocene causing the AALCB magmatisms. Jurassic to Cretaceous magmatic rocks with alkaline to calc-alkaline affinities in the north Lesser Caucasus indicates arc magmatism characteristics and continued to the west joining the Pontide magmatic belt in northeastern Turkey (Dilek, 2010; Zakaridze, 2007). Intense volcanic activities with acidic to basic composition were started in the AALCB during Eocene. Eocene volcanic rocks with alkaline to calc-alkaline nature (Figs. 3 and 4) indicate continental margin magmatism. Distribution patterns of the

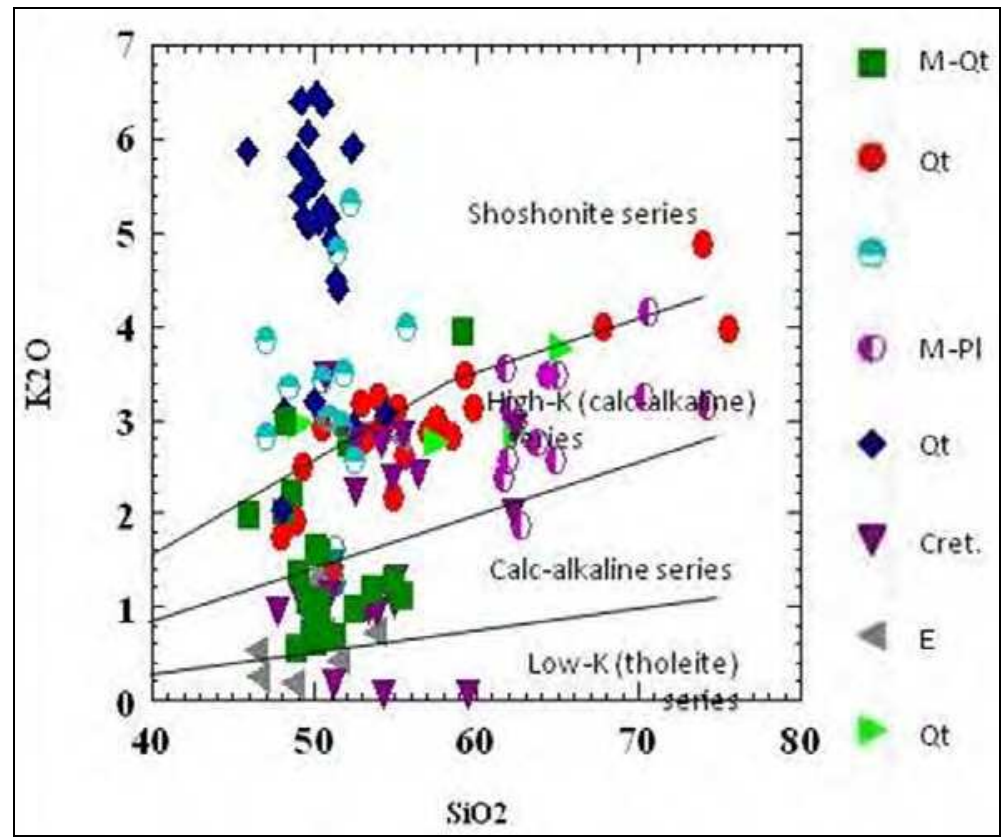

Fig. 3. $\mathrm{K}_{2} \mathrm{O}(\mathrm{wt} \%)$ versus $\mathrm{SiO}_{2}(\mathrm{wt} \%$ ) diagram for clasification of $\mathrm{NW}$ Iran volcanic rocks (Peccarillo and Taylor, 1976). The abbreviations are as follow: M-Qt: Mio-Pliocene to Quaternary(Kheirkhah et al., 2009), Qt: Quaternary (Dilek et al., 2010), E: Eocene (Dilek et al., 2010), M-Pl: Mio-Pliocene (Dilek et al., 2010), Qt: Quaternary (Ahmadzadeh et al., 2010), Cret: Cretaceous (Azizi et al., 2009), E: Eocene (Azizi et al., 2009), Qt: Quaternary (Ahmadzadeh et al., 2010). 
REEs (weak or absent Eu negative anomaly and more differentiated pattern of REEs) also are indicative of continental subduction zones (Fig. 5). Most of the samples (except some Cretaceous volcanics in SSZ) plotted in $(\mathrm{Nb} / \mathrm{Zr})_{\mathrm{n}}-\mathrm{Zr}-\mathrm{Zn}$ diagram clustered in the collision related and within plate fields (Fig. 6). In $\mathrm{Rb}-\mathrm{Y}+\mathrm{Nb}$ and $\mathrm{Nb}-\mathrm{Y}$ diagram (Pearce, 1996, 1984) they mainly plotted in the field of post collision granitoids (Fig. 7). In the $\mathrm{Hf}, \mathrm{Nb}, \mathrm{Ta}$ and $\mathrm{Rb}$ diagrams of Harris (1986), most of the samples plotted at the border of VAG, WPG and PostCollision fields (Fig. 8).

Following to the Eocene intense volcanic activities, Oligocene magmatic activities occurred in the form of intrusive bodies, in the AALCB. The composition of Oligocene intrusions is mainly acidic to intermediate with lesser amounts of mafic rocks (Fig. 9). They include granite, granodiorite, quartz monzonite, monzonite, syenite, syeno-diorite and gabbro which are intruded by lamprophyric to dacitic dykes. Based on the geochemical studies, the intrusive rocks are of different origins. Monzodiorites, gabbros and syenites show alkaline and shoshonitic nature and probably were originated from partial melting of lithospheric mantle, while the acidic rocks (granites, granodiorites and quartz monzonites) with high-K, calc-alkaline affinities (Fig. 8) show $\mathrm{C}$ type adakitic magma characteristics. They also show high amounts of $\mathrm{Ba}$ and $\mathrm{Sr}$ and originated from partial melting of lower mafic and potassic crust due to increase of the crust's thickness. Finally, the lamprophyrs are alkaline type and formed from the melting of OIB type metasomatized lithospheric mantle (Aghazadeh, 2010).

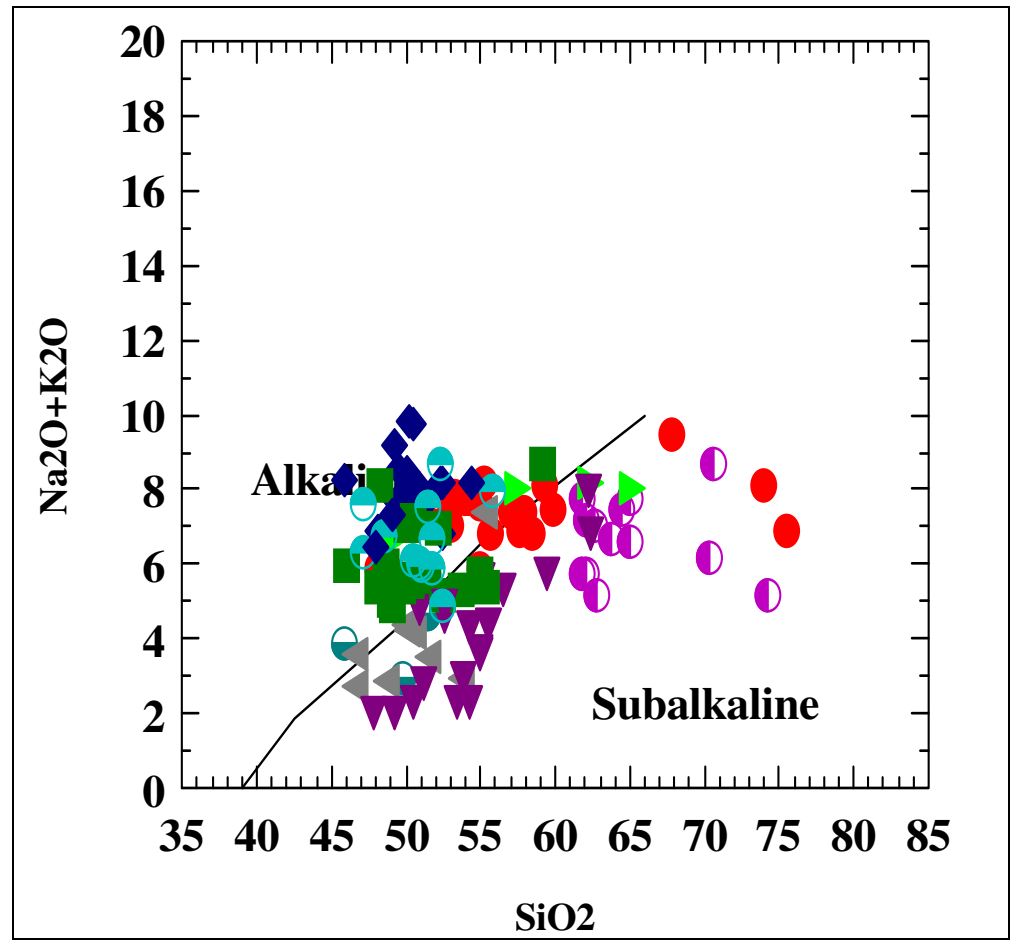

Fig. 4. Total alkali (wt\%) versus $\mathrm{SiO}_{2}(\mathrm{wt} \%)$ clasification of volcanic rocks (after Le Bas et al., 1986). (symbols as in Fig.3) 


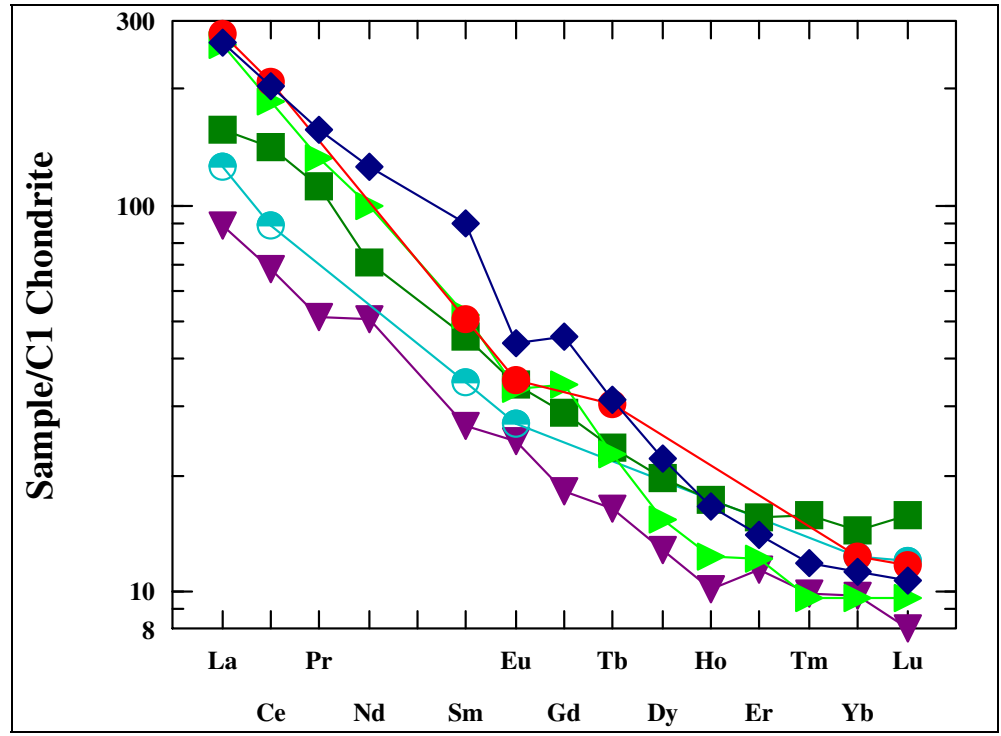

Fig. 5. C1 Chondrite normalized REE patterns for Meso-Cenozoic volcanic rocks in NW Iran. Mean values of REE used for each rock group. (symboles as in Fig. 3).

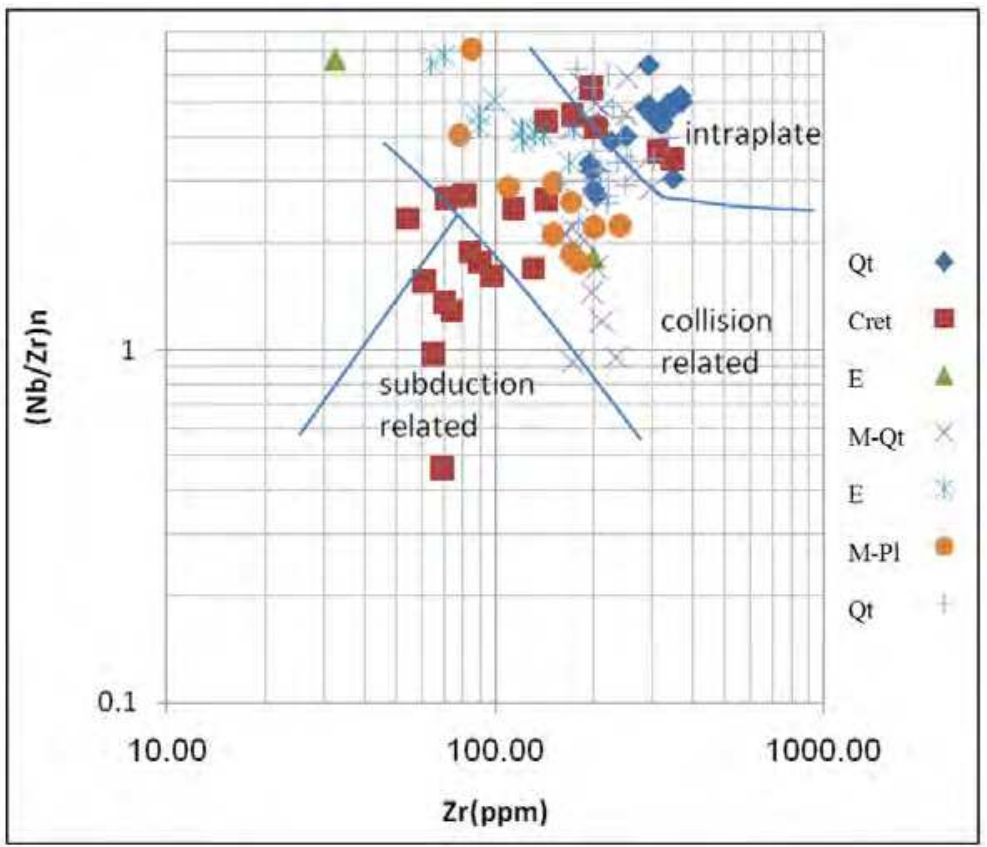

Fig. 6. (Nb/Zr) $)_{n}$ versus Zr (ppm) diagram (Thieblemont and Tegyey, 1994) for volcanic rocks. Most of the samples plotted in the collision related field. (Abbreviations as in Fig. 3). 

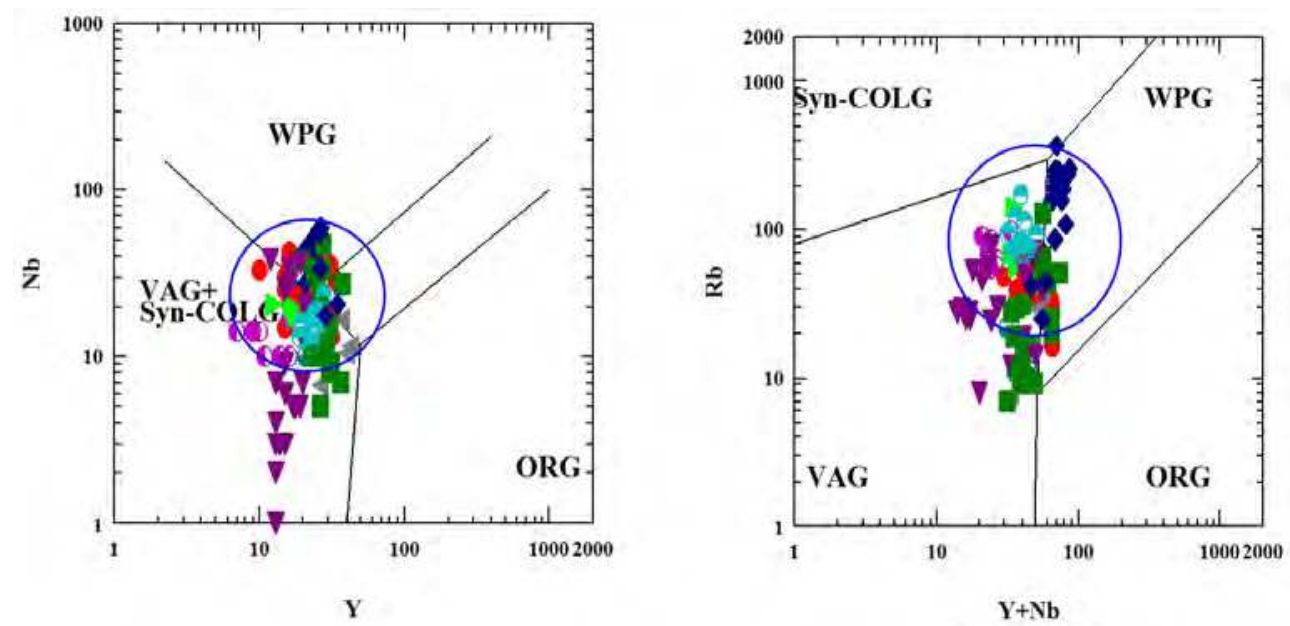

Fig. 7. Tectonic discrimination diagram of $R b$ versus $\mathrm{Yb}+\mathrm{Nb}$ and $\mathrm{Nb}$ versus $\mathrm{Y}$ (after Pearce et al., 1984 and 1996). Most of the samples plotted in the post collision field (blue circles). (symbols as in Fig.3)

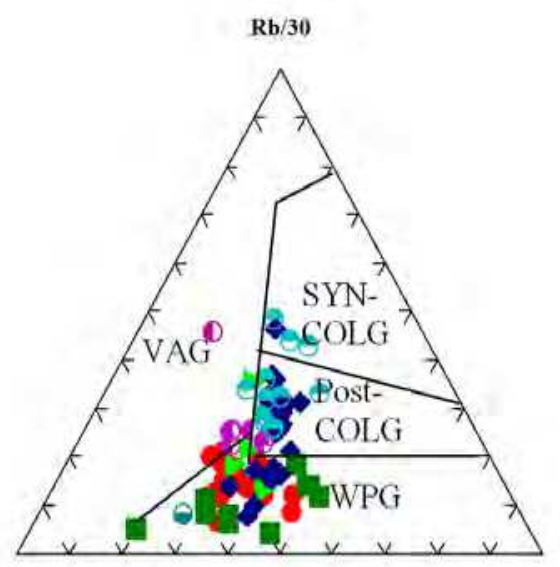

HI

$\mathrm{Ta} * 3$

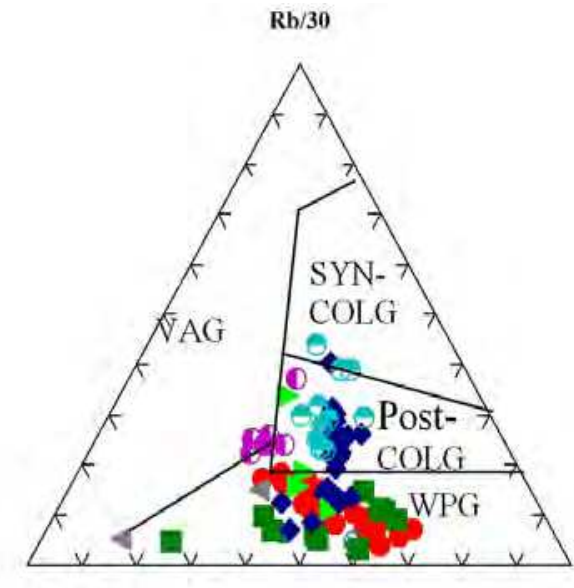

Hf

Fig. 8. Triangular diagrams of Harris et al. (1986), for various tectonic environments in collision zones. Most of the samples plotted at the border of VAG, WPG and Post-Collision field, which is characteristics of the post-collision magmatism. (symbols as in Fig. 3)

Field observations indicate that the acidic calc-alkaline rocks are older than intermediate to basic shoshonitic rocks. These observations are confirmed by zircon age dating of intrusive bodies of north and east of Ahar given by Aghazadeh (2010). The results of these dating indicate that the age of adakitic granodiorite is $31.8 \mathrm{Ma}$., gabbro-monzonite is $28 \mathrm{Ma}$ and syenite and melasyenite is $24-26 \mathrm{Ma}$. In $\mathrm{K}_{2} \mathrm{O}-\mathrm{SiO}_{2}$ diagram, lamprophyrs and synenites are plotted in shoshonite field and gabbros, monzonites and granites (resulted from their 
differentiation) belong to the high potassium series. Granites, granodiorites and quartz monzonites are situated in medium to high potassium calc-alkaline field (Fig. 10). In diagram of trace elements of Pearce $(1984,1996)$ and Thieblemont and Tegyey (1994), most of the samples belong to post collision environments and they have no direct relationships with subduction (Figs. 11 and 12).

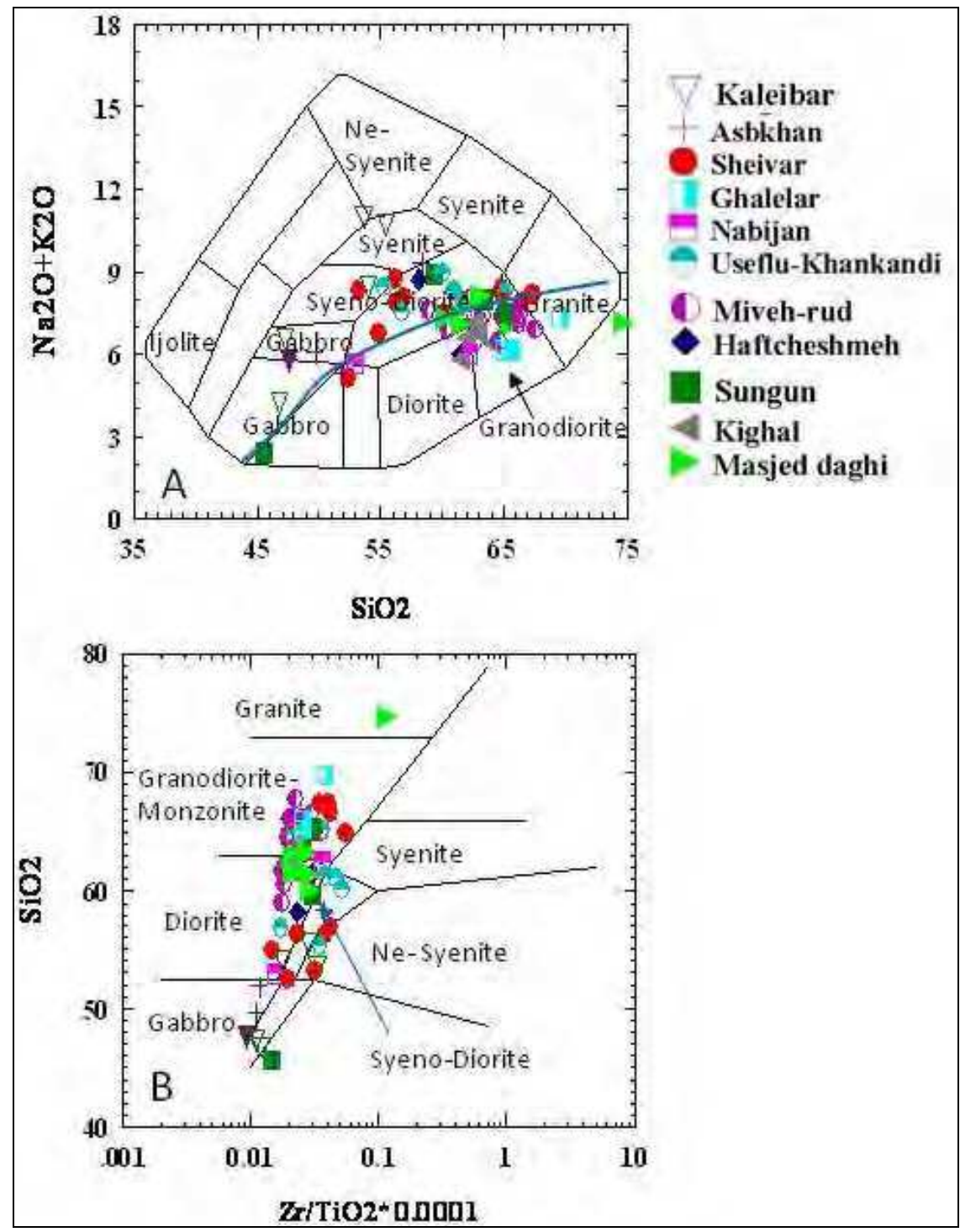

Fig. 9. Geochemical classification of the AALC plutons. (A) Using the total alkali versus $\mathrm{SiO}_{2}$ (Wilson, 1989); the blue line separates alkaline rocks from sub-alkaline. (B) $\mathrm{Zr} / \mathrm{TiO}_{2}$ versus $\mathrm{SiO}_{2}$ diagram of Winchester and Floyd (1977). 


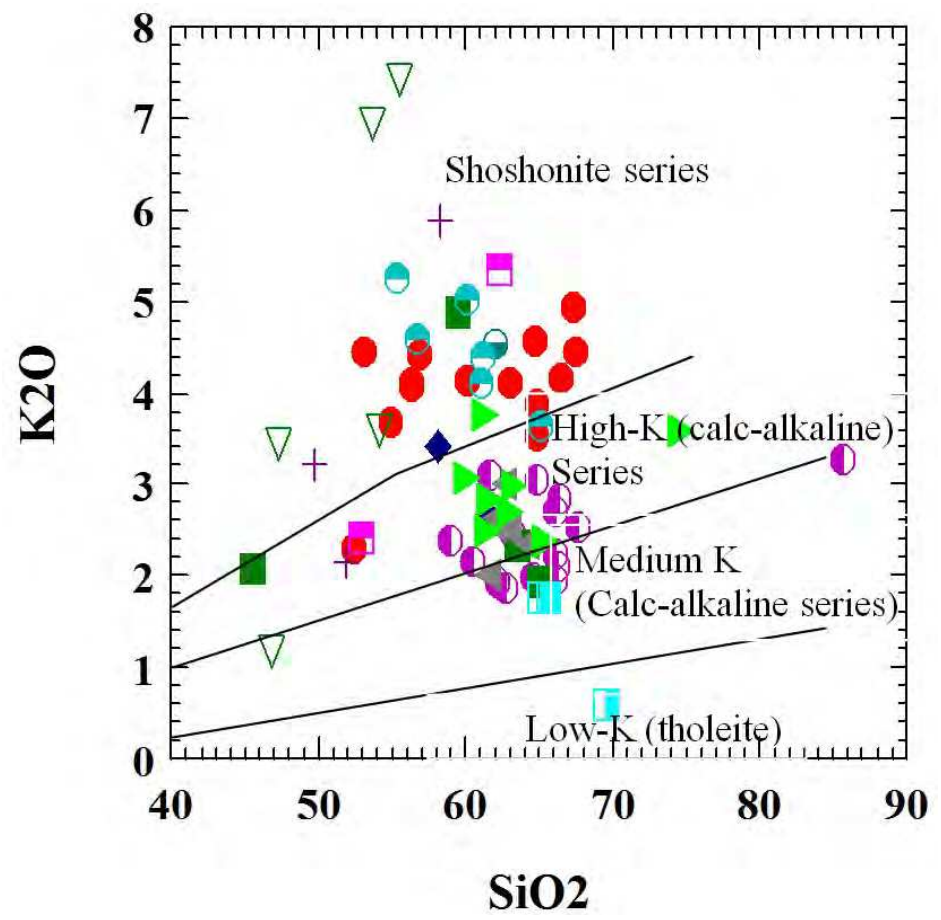

Fig. 10. $\mathrm{K}_{2} \mathrm{O}(\mathrm{wt} \%)$ versus $\mathrm{SiO}_{2}(\mathrm{wt} \%$ ) diagram for clasification of the Arasbaran Oligicene plutonic rocks (Le Maitre et al.,1989; Rickwood, P.C., (1989). (symboles as in Fig.9).
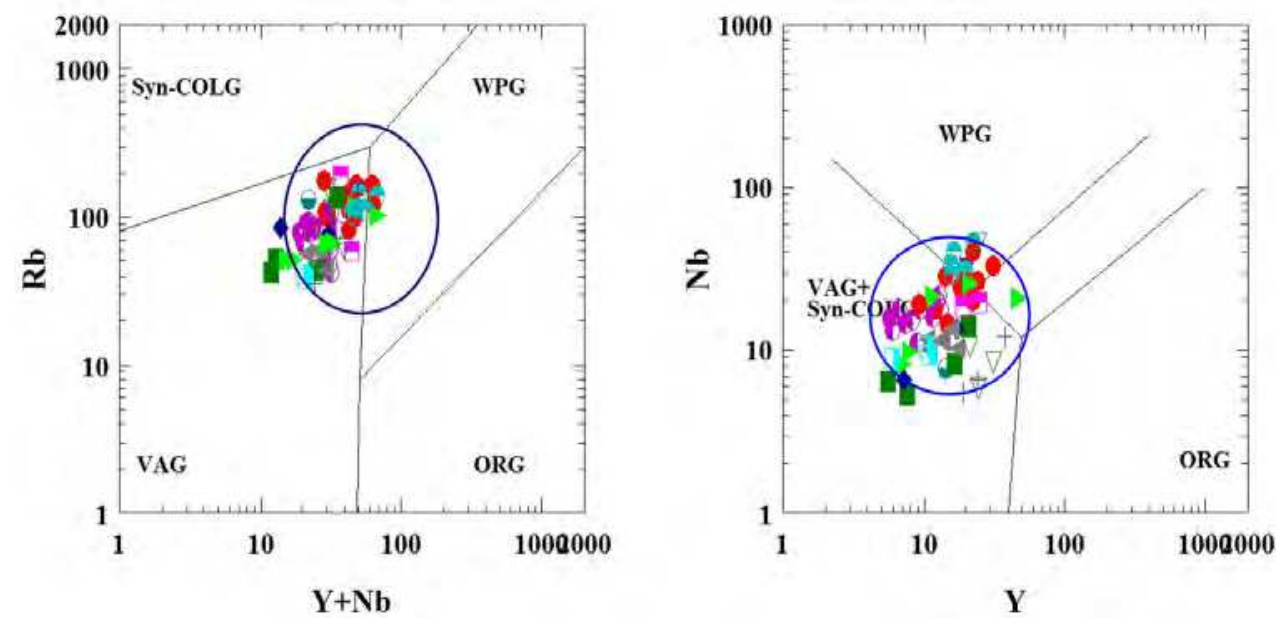

Fig. 11. Tectonic discrimination diagram of $\mathrm{Rb}$ versus $\mathrm{Yb}+\mathrm{Nb}$ and $\mathrm{Nb}$ versus $\mathrm{Y}$ (after Pearce et al., 1984; Pearce, 1996). Most of the samples plotted in post collision field (blue circle). (symboles as in Fig.9). 


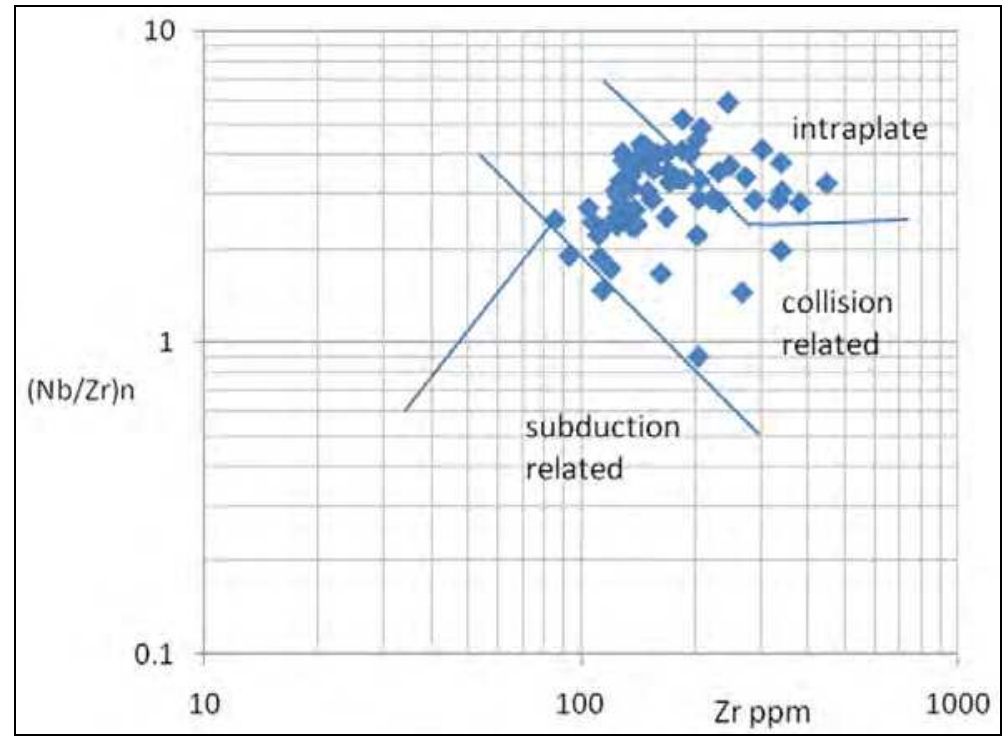

Fig. 12. $(\mathrm{Nb} / \mathrm{Zr})_{\mathrm{n}}$ versus $\mathrm{Zr}(\mathrm{ppm})$ diagram (Thieblemont and Tegyey, 1994) for the volcanic rocks. Most of the samples plotted in the collision related field.

Oligocene intrusive bodies could be divided into two groups based on their structure, texture and the depth of emplacement: (1) Large intrusive bodies (batholites) with medium to coarse grained texture that formed at 3 to $4 \mathrm{~km}$ depth such as Sheivar Dagh, Khankandi, Youseflu and Kaleibar are poorly mineralized, and mineralization associated with them mainly occurs in the contact zone with their host rocks or within the country rocks. These intrusive bodies show high K calc-alkaline to shoshonitic affinity. (2) Sub-volcanic bodies with porphyritic textur and calc-alkaline character formed at 1-2 $\mathrm{km}$ depth and are associated with remarkable mineralization such as Sungun, Mivehrud, Masjed Daghi and Haftcheshmeh deposits. Most of the mineralization occurs in quartz monzonite-monzonite. Microscopic investigations of rock samples of quartz monzonite- monzonite indicate that amphibole and biotite phenocrysts are paragentically earlier than other minerals. This indicates that the amount of water in the original magma was more than $3 \%$ in the crystallization stage (Whitney, 1975; Burham, 1979; Whitney and Stromer, 1985). The lack of Eu negative anomaly may be assumed to be the result of high oxygen fugacity in the original magma, because the high oxygen fugacity oxidizes $\mathrm{Eu}^{2+}$ to $\mathrm{Eu}^{3+}$ and so it can not enter into the plagioclase structure (Hezarkhani, 2006). In addition to bearing water and oxidizing state of the primary magma, replacement in the lower depth caused water saturation and fluid separation in primary stages of crystallization of original magma followed by mineralization.

After Oligocene intrusion phase in the Arasbaran area the next magmatic activities occurred in the Late Miocene and continued to Quaternary. The Late Miocene-Pliocene magmatic rocks are mostly acidic in composition (granite-granodiorite) and they are in the form of sub-volcanic bodies and/or volcanic domes (such as Ghalehlar and Bohlul Daghi), that could be observed in the southwestern Arasbaran area. These magmatic rocks have alkaline 
adakitic nature and they are probably related to post collision processes such as slab break off or delamination (Jahangiry, 2007; Karimzade, 2004). Adakitic magmatism in the PlioQuaternary was followed by basic alkaline volcanism. At first, the alkali basic magma was sodic in composition changing upward to more potassic in composition, and bears leucite phenocrysts. The Plio-Quaternary volcanic rocks include andesite, basalt-andesite, tephritebasalt, leucite basalt and tephrite. The amounts of $\mathrm{K}_{2} \mathrm{O}$ and $\mathrm{MgO}$ and the $\mathrm{K}_{2} \mathrm{O} / \mathrm{Na}_{2} \mathrm{O}$ ratio in these rocks are high enough to classify them as high or even ultra potassic rocks (Fig. 3). They characterized with significant enrichment in LILE and LREE and depletion in highfield-strength elements. So, the metasomatized lithospheric mantle composed of garnet lherzulite and high fugacity of $\mathrm{CO}_{2} / \mathrm{H}_{2} \mathrm{O}$ ratio played a significant role in their genesis (Ahmadzadeh, 2010 and Khezerlu, 2008).

\subsection{Discussion and conclusions}

Two oceanic island arcs magmatism, one in SSZ (Songhor-Baneh) and the other in the north Lesser Caucasus are distinguished. Except of these two oceanic arcs, all of the magmatic rocks in the SSZ, UDMB and AALCB are related to continental margins. As going toward north and south from Tabriz fault, the magmatism becomes older and its alkalinity decreases.

SSZ magmatic rocks that are mostly intrusive type were primarily related to an active subduction margin and later on about 80 million years ago reveals post-collision magmatic characteristics. There is no unanimity for the time of collision between the Arabian plate and SSZ. Some geologists believe that the collision had been occurred in the Late CretaceousEarly Paleocene (Moaiyed, 2001; Ghalamghash, 2009; Mazhari, 2009), while some others think of the collision had been occurred during Middle-Late Miocene (Omrani, 2009; Azizi, 2009). However, the rare earth and trace elements diagrams indicate that the major plutonic and volcanic rocks of the UDMB and SSZ belong to the post-collision environment. So, it may be concluded that the time of collision is more likely Late Cretaceous-Early Paleocene, and the following magmatisms are not directly related to subduction. On the other hand they may be related to the post collisional magmatism such as slab break off and delamination.

From Tabriz fault toward north to Lesser Caucasus, a reverse zonation is observed, that means the age of magmatic rocks increases toward north. In the vicinity of Tabriz fault the magmatic rocks are of Miocene-Quaternary age, while in the Arasbaran region and southern part of Lesser Caucasus, the magmatism belongs to Eocene- Oligocene, and from Sevan-Akera suture zone toward north, the magmatic rocks are related to Jurassic-Late Cretaceous events. However, in the study area the older rocks (Late Mesozoic) show magmatic arc characteristics, while the younger rocks (Cenozoic) are indicative of postcollision environments.

In each side of the Tabriz fault, the zoning is reversed relative to the other side and it could not be justified to be related to one subduction zone. It is more likely to belong to two separate subduction zones. It seems that in the Zagros region the subduction relates to southern Neo-Tethys, while in Lesser Caucasus-Arasbaran, this event relates to the northern Neo-Tethys, and these two events justify the magmatism and geotectonic evolution of the region. On the other hand, a northern ocean was existed between the north of Central Iran, south Armenia and Tauride blocks with Eurasian plate, and a southern ocean was between 
the above blocks with Arabian plate. The oceans were closed during convergence of the Arabian plate moving northward towards Eurasian plate. The dip direction of subduction in southern ocean is supposed to be northeast, while there are many controversies about the dip direction of the subducting slab of the northern ocean, although magmatic and petrogenetic characteristics of the area and the distribution of the magmatic rocks in time and space are indicative of probable southwest dip direction for subducting slab of the northern ocean.

Gold Mineralization in the SSZ were previously supposed to be related to orogenic events, while recently it is believed that they are intrusion related type mineralization that belongs to the Eocene post collision events. Recent investigations have also indicated the probable existence of porphyry type mineralization in the Hashtrud, a part of northwestern UDMB.

Carlin and epithermal type gold mineralizations are associated with Miocene adakitic magmatism, i.e. in Ghorveh and Takab region. Oligocene magmatism in the Arasbaran zone is associated with remarkable porphyry, skarn and vein type $\mathrm{Cu}-\mathrm{Mo}-\mathrm{Au}$ mineralization. Epithermal gold mineralization is accompanying both Oligocene and Miocene magmatisms.

In general, the northern belt including the AALCB is highly mineralized compare to the southern belt including the UDMB and SSZ that have relatively poor mineralization.

\section{Acknowledgements}

This study was supported by the Geological Survey of Iran (GSI). We acknowledge the faculty research grants from Miami University in support of fourth author work in eastern Turkey, Azerbaijan, and Northern Iran. Special thanks to Mr M.B. Dorri, N. Abedian, and B. Borna (GSI) for logistical support.

\section{References}

Aghanabati, A. (1993) Geological map of the Middle East, scale: 1:5,000,000. Geological Survey of Iran.

Aghazadeh, M., Castro, A., Rashidnejad Omran, N., Emami, M.H., Moinvaziri, H. and Badrzadeh, Z. (2010) The gabbro (shoshonitic)-monzonite-granodiorite association of Khankandi pluton, Alborz Mountains, NW Iran, Journal of Asian Earth Sciences, 38, 199-219.

Ahmadzadeh, Gh., Jahangiri, A., Lentz, D. and Mojtahedi, M. (2010) Petrogenesis of PlioQuaternary post-collisional ultra-potassic volcanism in NW of Marand, NW Iran. Journal of Asian Earth Sciences, 39, 37-50.

Alavi, M., (2007) Structures of the Zagros fold-thrust belt in Iran. American Journal of Science, 307, 1064-1095.

Azizi, H. and Moinvaziri, H., (2009) Review of the tectonic setting of Cretaceous to Quaternary volcanism in northwestern Iran. Journal of Geodynamics, 47, 167179. 
Bazhenov, M., Burtman, V.S. and Levashova (1996) Lower and Middle Jurassic paleomagnetic results from the South Lesser Caucausus and the evolution of the Mesozoic Tethys Ocean. Earth and Planetary Science Letter, 141, 79-89.

Berberian M., Amidi, S.M. and Babakhani, A. (1981) Discovery of the Qaradagh ophiolite belt, the southern continuation of the Sevan-Akera (Caucasus) ophiolite belt in northern Iran (Ahar quadrangle), a preliminary field note, GSI.

Berberian, M. and King, G.C.P., (1981) towards a paleogeography and tectonic evolution of Iran. Canadian Journal of Earth Sciences, 18, 210-265.

Blourian, G.H. (1994) Petrology of the Tertiary volcanic rocks in the northern Tehran: [M.Sc. thesis], Tehran, Iran, University of Tarbiat Moallem, $145 \mathrm{pp}$.

Burnham, C.W. (1979) Magmas and hydrothermal fluids. In: Barnes, H.L. (Ed.), Geochemistry of Hydrothermal Ore Deposits. Wiley, New York, 71-136.

Dewey, J.F., Pitman, W., Ryan, W., and Bonin, J. (1973) Plate tectonics and the evolution of the Alpine system. Geological Society of America Bulletin, 84, 3137-3180.

Dilek, Y., Imamverdiyev, N. and Altunkaynak, S. (2010) Geochemistry and tectonics of Cenozoic volcanism in the Lesser Caucasus (Azerbaijan) and the peri-Arabian region: Collision-induced mantle dynamics and its magmatic fingerprint. International Geology Review, 52, 536-578.

Dilek, Y. and Furnes, H. (2009) Structure and geochemistry of Tethyan ophiolites and their petrogenesis in subduction rollback systems. Lithos:

Doi:10.1016/j.Lithos.2009.04.022.

Galoyan, Gh., Rolland, Y., Sosson, M., Corcini, M., Billo, S., Verati, Ch. and Melkonyan, R. (2009) Geology, geochemistry and ${ }^{40} \mathrm{Ar} /{ }^{39} \mathrm{Ar}$ dating of Sevan ophiolites (Lesser Caucasus, Armenia): Evidence for Jurassic back-arc opening and hot spot event between the South Armenia block and Eurasia. Journal of Asian Earth Sciences, 34, 135-153.

Ghaderi, M., Ramazani, J. and Bowring, S. (2009) Ages of plutonic activity in the SanandajSirjan zone, Iran: Implication for plate convergence and Zagros collision. Geological Society of AmericaAbstracts with Programs, 41, No. 7, p. 482.

Ghalamghash, J, Nedelec, A, Bellon, B, Vousoughi, Abedini, M, and Bouchez, J.L. (2009) The Urumieh plutonic complex (NW Iran): A record of the geodynamic evolution of the Sanandaj-Sirjan zone during Cretaceous times - Part I: Petrogenesis and K/Ar dating. Journal of Asian Earth Sciences, 35, 401-415

Harris, N.B.V., Pearce, J.A. and Tindle, A.G., (1986) Geochemical characteristics of collision zone magmatism. In: Coward M.P. and Ries, A.C. (Eds), Collision Tectonics. Geological Society of London, Special Publication. 19, 67-81.

Hessami, K., Koyi, H.A. and Talbot, C.J. (2001) The significance of strike slip faulting in the basement of the Zagros fold and thrust belt. Journal of Petroleum Geology, 24, 528.

Hezarkhani, A. (2006) Petrology of the intrusive rocks within the Sungun Porphyry Copper Deposit. Journal of Asian Earth Sciences, 26, 683-693.

Jahangiri A. (2007) Post-collisional Miocene adakitic volcanism in NW Iran: Geochemical and geodynamic implications, Journal of Asian Earth Science, 30, 433-447. 
Jamali, H., Dilek, Y, Daliran, F., Yaghubpur, A. and Mehrabi, B. (2010) Metallogeny and tectonic evolution of the Cenozoic Ahar- Arasbaran volcanic belt, northern Iran. International Geology Review, 53, 608-630.

Karimzadeh, A., (2004) Marano volcanic rocks, East Azerbaijan province, Iran, and associated Fe mineralization. Journal of Asian Earth Sciences, 24, 11-23.

Keskin, M., (2003) Magma generation by slab steepening and break off beneath a subduction-accretion complex: An alternative model for collision-related volcanism in Eastern Anatolia. Geophysical Research Letters, 30, No. 24, 1-4.

Kheirkhah M., Allen M.B. and Emami M. (2009) Quaternary syn-collision magmatism from the Iran/Turkey borderlands, Journal of Volcanology and Geothermal Research, $182,1-12$.

Khezerlu, A.A., Amini, S. and Moayed, M. (2008) Petrology, geochemistry and mineralography of potassic to ultra-potassic (mainly shoshonitic) lavas of NW Marand (Azerbaijan). Journal of Science, Tarbiat Moallem University, 8, No. 3, 183204.

Le Bas, M.J., Le Maitre, R.W., Streckeisen, A., and Zanettin, B. (1986) A chemical classification of volcanic rocks based on total alkali-silica content. Journal of Petrology, 27, 745-750.

Le Maitre R.W., Bateman P., Dudek A., Keller J., Lameyre Le Bas M.J., Sabine P.A., Schmid R., Sorensen H., Streckeisen A., Woolley A.R. and Zanettin B. (1989) A classification of igneous rocks and glossary of terms. Blackwell, Oxford.

Mazhari, S. A., Bea, F., Amini, S., Ghalamghash, J., Molina, J. F., Montero, P., Scarrow, J. H. and Williams, I. S. (2009) The Eocene bimodal Piranshahr massif of the SanandajSirjan Zone, NW Iran: a marker of the end of the collision in the Zagros orogen, Journal of the Geological Society, London, 166, 1-17. doi: 10.1144/0016-76492008022 .

Mehrabi, B., Mahmoudi, Sh., Masoudi, F. and Crfou, F. (2009) Mesozoic and Cenozoic U- Pb ages and magmatic history of granitoid bodies in the northern Sanandaj-Sirjan metamorphic zone, Iran. Geological Society of America, 41, No. 7, 481pp.

Mehrabi, B., Yardley, D. and Cann, R. (1999) Sediment-hosted disseminated gold mineralization at Zarshuran, NW Iran, Mineralium Deposita, 34, No: 7, 673696.

Moayyed, M., (2001) Geochemistry and petrology of volcano-plutonic bodies inTarum area, Tabriz University, [Ph.D. thesis]: 256 pp. (in Persian).

Moinevaziri, H., Aziz, H., Mehrabi, B., Izadi, F. (2008) Oligocene magmatism in the Zagros thrust zone (Sahneh-Marivan axis): the Second period of the Neotethyan subduction in the Paleogene. Tehran Universit. J. Sci. (in Persian) 34 (1), 113122.

Moritz, R., Ghazban, F., and Singer, B.S. (2006) Eocene gold ore formation at Muteh, Sanandaj-Sirjan tectonic zone, Western Iran: A result of late-stage extension and exhumation of metamorphic basement rocks within the Zagros Orogen. Economic Geology, 101, 1497-1524. 
Omrani, J, Agard, Ph., Whitechurch, H, Benoit, M., Prouteau Gand Jolivet, L., (2008) Arcmagmatism and subduction history beneath the Zagros Mountains, Iran: A new report of adakites and geodynamic consequences. Lithos, 106, 380-398

Pearce, J.A., (1996) Sources and settings of granitic rocks. Episodes, 19, 120-125.

Pearce, J.A., Harris, N.B.W., and Tindel, A.J. (1984) Trace element discrimination diagram for the tectonic interpretation of granitic rocks. Journal of Petrology, 25, 956- 983.

Richards, J. P. (2009) Postsubdution porphyry Cu-Au and epithermal Au deposits: Products of remelting of subduction-modified lithosphere. Geological Society of America.

Richards, J. P., Wilkinson, D. and Ullrich, Th. (2006) Geology of the Sari Gunay epithermal gold deposit, Northwest Iran. Economic Geology, 101, No. 8, 1455- 1496.

Rickwood, P.C., (1989) Boundary lines within petrology diagrams which use oxide of major and minor elements. Lithos, 22, 247- 264.

Rolland, Y., Billo, S., Corsini, M., Sosson, M. and Galoyan, G., (2009) Blueschists of the Amassia-Stepanavan Suture Zone (Armenia): Linking Tethys subduction history from E-Turkey to W-Iran. International Journal of Earth Sciences, 98, 533-550.

Shengor, A.M.C. and Natal'in, B.A. (1996) Paleotectonics of Asia: Fragments of a synthesis, in Yin, A., and Harrison, T.M., eds., The Tectonic Evolution of Asia. Cambridge: Cambridge University Press, 486-640

Shengor, A.M.C. (1990) Anew model for the Late Paleozoic Mesozoic tectonic evolution of Iran and implications for Oman, in Robertson, A.H.F., Searle, M.P. and Ries, R.C., editors, The Geology and Tectonics of the Oman Region :London. Geological Society, Special Publication, 49, 797-831.

Sosson, M., Rolland, Y., Corcini, M., Danelian, T., Stephan, J.F., Avagyan, A., Melkonian, R., Jrbashian, R., Melikian, L. and Galoian, G. (2005) Tectonic evolution of Lesser Caucasus (Armenia) revisited in the light of new structural and stratigraphic results. Geophysical Research Abstracts, 7, 06224.

Takin, M. (1972) Iranian Geology and continental drift in the Middle East. Nature, 235, 147150.

Talebian, M. and Jackson, J., (2004) Areappraisal of earthquake focal mechanisms and active shortening in the Zagros mountains of Iran. Geophysical Journal International, 156, 506-526.

Thieblemont, D. and Tegyey, M., (1994) Unediscrimination ge'ochimique desrochesdiffe'rencie'este'moindeladiversite' d'origineetdelasituationtectoniquedes magmas: Comptes Rendusdel' Acade' miedessciences, Paris, 319, No.2, 87-94.

Whitney, J.A. (1975) Vapor generation in quartz monzonite magma: a synthetic model with application to porphyry copper deposits. Economic Geology, 70, 346-358.

Whitney, J.A. and Stormer, J.C. (1985) Mineralogy, petrology and magmatic conditions from the Fish Canyon Tuff, central San Juan volcanic field, Colorado. Journal of Petrology, 26, 726-762.

Wilson M. (1989) Igneous petrogenesis, Unwin Hyman, London. 
Winchester, J.A. and Floyd, P.A. (1977) Geochemical discrimination of different magma series and their differentiation products using immobile elements. Chemical Geology, 20, 325-343.

Zakariadze, G.S., Dilek, Y., Adamia, Sh.A., Oberha“nsli, R.E., Karpenko, S.F., Bazylev, B.A. and Solov'eva, N. (2007) Geochemistry and geochronology of the Neoproterozoic Pan-African basement of the Transcaucasian Massif (Republic of Georgia) and implications for island arc evolution in the Late Precambrian Arabian-Nubian Shield. Gondwana Research, 11, 92-108, Doi: 10.1016/j.gr.2006.05.012. 


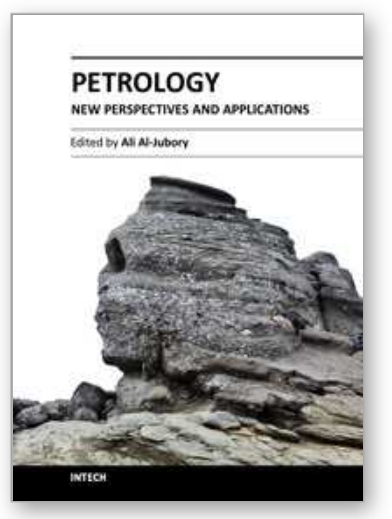

\author{
Petrology - New Perspectives and Applications \\ Edited by Prof. Ali Al-Juboury
}

ISBN 978-953-307-800-7

Hard cover, 224 pages

Publisher InTech

Published online 13, January, 2012

Published in print edition January, 2012

Petrology, New Perspectives and Applications is designed for advanced graduate courses and professionals in petrology. The book includes eight chapters that are focused on the recent advances and application of modern petrologic and geochemical methods for the understanding of igneous, metamorphic and even sedimentary rocks. Research studies contained in this volume provide an overview of application of modern petrologic techniques to rocks of diverse origins. They reflect a wide variety of settings (from South America to the Far East, and from Africa to Central Asia) as well as ages ranging from late Precambrian to late Cenozoic, with several on Mesozoic/Cenozoic volcanism.

\title{
How to reference
}

In order to correctly reference this scholarly work, feel free to copy and paste the following:

Hemayat Jamali, Abdolmajid Yaghubpur, Behzad Mehrabi, Yildirim Dilek, Farahnaz Daliran and Ahmad Meshkani (2012). Petrogenesis and Tectono-Magmatic Setting of Meso-Cenozoic Magmatism in Azerbaijan Province, Northwestern Iran, Petrology - New Perspectives and Applications, Prof. Ali Al-Juboury (Ed.), ISBN: 978-953-307-800-7, InTech, Available from: http://www.intechopen.com/books/petrology-new-perspectivesand-applications/petrogenesis-and-tectono-magmatic-setting-of-meso-cenozoic-magmatism-in-azerbaijanprovince-northwes

\section{INTECH}

open science | open minds

\author{
InTech Europe \\ University Campus STeP Ri \\ Slavka Krautzeka 83/A \\ 51000 Rijeka, Croatia \\ Phone: +385 (51) 770447 \\ Fax: +385 (51) 686166 \\ www.intechopen.com
}

\author{
InTech China \\ Unit 405, Office Block, Hotel Equatorial Shanghai \\ No.65, Yan An Road (West), Shanghai, 200040, China \\ 中国上海市延安西路65号上海国际贵都大饭店办公楼 405 单元 \\ Phone: +86-21-62489820 \\ Fax: +86-21-62489821
}


(C) 2012 The Author(s). Licensee IntechOpen. This is an open access article distributed under the terms of the Creative Commons Attribution 3.0 License, which permits unrestricted use, distribution, and reproduction in any medium, provided the original work is properly cited. 